\title{
Analysis of the current situation of two wheels tractors in Mexico
}

\begin{abstract}
In Mexico, $34 \%$ of the population is dedicated to agricultural tasks with very small land areas, $85 \%$ of the farmers do not have more than 5 ha of arable land, among them $90 \%$ do not reach 3 ha which indicates the need to use light machinery, an option nowadays is the introduction of two wheels tractor for its low acquisition cost. At present, there are few works on two wheels tractors in Mexico, so this is the main objective of this article, to analyze the situation of the design, manufacture and testing of these agricultural machines in Mexico. From the analysis of the current situation of the two wheeled tractor in Mexico, it is concluded that measures must be taken to start the manufacture of this type of tractors in the country, as it would be the first step to start the manufacture of tractors in Mexico, because both of these simple and other types of tractors are of foreign design and only some two-axis models are assembled in Mexico, it would be beneficial to start at least with these simple machines, as there are national design prototypes, there is also infrastructure for the evaluation and testing, only the decision of entrepreneurs and government support to start manufacturing in the country is missing.
\end{abstract}

Keywords: Mexico, two wheels tractor, farm mechanization, agricultural machines, tractor
Volume 4 Issue I - 2020

\author{
Jaime Cuauhtemoc Negrete \\ Professor of mechanization and agricultural machines, \\ Autonomous Agrarian Antonio Narro University, Mexico
}

Correspondence: Jaime Cuauhtemoc Negrete, Professor of mechanization and agricultural machines, Autonomous Agrarian Antonio Narro University, Mexico, Email temone@gmail.com

Received: December 13, 2019 | Published: February II, 2020
Abbreviations: INIFAP, national institute of forestry, agricultural and livestock research; CENEMA, national center of agricultural machinery standardization; OCIMA, certification body for agricultural implements and machinery

\section{Introduction}

In Mexico, $34 \%$ of the population is dedicated to agricultural tasks with very small land areas, $85 \%$ of the farmers do not have more than 5 ha of arable land, among them $90 \%$ do not reach 3 ha which indicates the need to use light machinery, an option nowadays is the introduction of two wheels tractor for its low acquisition cost. This has a very important current relevance due to the situation of national agriculture, poverty, food insecurity, low productivity, migration among other factors, which can be reduced through agricultural mechanization Emami et al. ${ }^{1}$ Mrema et al. ${ }^{2}$ Takeshima et al. $^{3}$ \& Takeshima et al. ${ }^{4}$ which can decrease the cost of production, reduce drudgery, improve the timeliness of operation, enhance the crop productivity, and finally increase the household income Pingali ${ }^{5}$ \& Sims and Kienzle. ${ }^{6}$

Agricultural mechanization is a crucial input for agricultural production, and one that has historically been neglected in the context of developing countries like ours. Through the Agricultural Mechanization, economic growth is promoted through higher yield per hectare and expansion of the cultivated area, either by incorporation of new land or by the possibility of carrying out more than one plantation per year, in the same area unit. This should rethink public policies to promote, which should encourage research, teaching and development of agricultural machinery, consistent with the average size of agricultural properties. Negrete. ${ }^{7}$ Most authors on agricultural mechanization agree that it increases productivity. Cadena, ${ }^{8}$ Soto,${ }^{9}$ Binswanger, ${ }^{10}$ \& Negrete. ${ }^{11-14}$ They are capital goods regardless of their size that increase the productivity of agriculture because they are considered to have the property of being diffusers of technological progress. Agricultural productivity is linked with the availability of farm power. Bullocks meet power requirement of marginal and small farms (less than 2 ha) with associated limitations. Tractors meet requirements of large farms (above 6 ha). Power tillers are imagined as appropriate source of farm power of medium farms $(2-6 \mathrm{ha}) .^{15}$ Also power tiller or two wheels tractors may be considered as the most suitable power source for mechanization small and medium size farms, and also considered as a potential source for rural employment and an alternative source of income generation for unemployed rural youth. ${ }^{16}$ At present, there are few works on two wheels tractors in Mexico, so this is the main objective of this article, to analyze the situation of the design, manufacture and testing of these agricultural machines in Mexico.

\section{Material and methods}

An intense search was conducted on government databases, manufacturers, sales and resellers web pages, internet, journals, books, university thesis and others.

\section{Literature review}

\section{Definition}

The vehicles of tractors of a single axis or two wheels tractor, are special self-propelled vehicles, of an axis, airships by braces by a driver who marches on foot. Certain two wheels tractor can also be directed from a seat incorporated to a trailer or agricultural machine or to an implement or auxiliary frame with wheels. Also called hand tractor, motor cultivator, and is a single-axle tractor, it is widely used in Asia mainly where it is also known as iron buffalo or steel buffalo, and in some regions of Europe. That do not usually exceed $15 \mathrm{KW}$ $(20 \mathrm{hp})$ of power. We can distinguish 3 types of two wheels tractor in relation to their mass and motor power. ${ }^{17}$ Those of lesser power 
are used in Asia mainly because they are used in wetlands for rice production, which means that less power is required, but in countries where dry land is plowed, more power is required, for example in some regions of Europe, where two wheels tractors of greater power are used. One of the biggest drawbacks of the two wheels tractors is its lack of normalization fundamentally in relation to the power takeoff, which is aggravated by the profusion of brands that exist, in this way there is no interchangeability between the two wheels tractors and the implements of different brands. ${ }^{17}$ Use rubber tires for dry land work and when used to pull a trailer, steel tires are used to work the wet ground. The implements that can be adapted are: Plowing bars, Plowing discs, Cultivators, Sprinklers, stationary pumps, electric power plants, Trailers.]

\section{Background}

A $9 \mathrm{~kW}$ motor-cultivator with two operators is capable of plowing one hectare in one day, while the fuel used depends on the size of the engine and working conditions, and is in the range of 2-5 liters per hour. Most people do not understand the importance that two wheels tractor play in the mechanization process of some developing nations such as Latin American countries, unlike some in southern and Eastern Europe. This is due to the confusion in names and the minimization in their importance for small farmers.

During modern years two-wheel tractors have been more adapted to sulkies to reduce operator fatigue and increase tractor productivity with an increase in powers. This predisposition occurs specially in Europe. New special uses have been developed for two-wheel tractors such as drilling holes, cutting wood and moving snow. Also there has been detected a tendency to substitute for gasoline engines, air-cooled diesel engines of similar speed, for better reduced consumption. ${ }^{18}$

\section{Results}

\section{Two wheels tractors designs in Mexico}

According to Negrete, ${ }^{12}$ there has not been a tractor designed and manufactured in Mexico for producers of small agricultural land, or complicated reliefs with steep slopes, there are only those who have already made proposals and recommendations for the manufacture of tractors, according to the producers of small rural properties.

\section{High clearance two wheel tractor}

Developed in Davis, California by Lara, ${ }^{19}$ as part of his doctoral thesis work, and continuing his development at the FIME School of Engineering at the University of Guanajuato, as part of the alternative to provide power to the sector of subsistence agriculture in Mexico.

In a single-axle and two-wheel tractor it does not have front wheels and steering mechanism then it is less expensive than a twoaxle and four-wheel tractor at the same power level, however due to the difference in operator fatigue It is more convenient to operate. Due to the above reasons, the one-axle tractor was chosen, which can be converted into a 4-wheel drive with the assembly of a small seat, this two wheels tractor has the unique characteristic of having more clearance than commercial conventional two wheels and thus to be able to be used when the plants show greater growth. The high clearance two wheel tractor is equipped with a $5.8 \mathrm{~kW}(7.77 \mathrm{hp})$ gasoline engine, at $3600 \mathrm{rpm}$. This power is due to the fact that the designer of this two wheels tractor found that for the subsistence agriculture sector in Mexico the optimum power The average property size ( $8 \mathrm{ha}$ ) is 5.16 kW (6.91 Hp) (Figure 1).

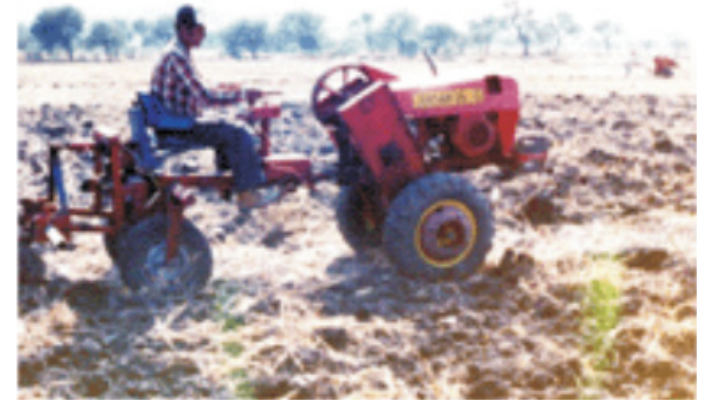

Figure I Two wheeled tractor high clearance. ${ }^{24}$

\section{Agricultural two wheels system}

Zarate. ${ }^{20} \mathrm{He}$ proposes the design of an Agricultural two wheels System as part of his Industrial Designer thesis work at UNAM Mexico. It has a 4-stroke single-cylinder gasoline engine, cast iron type L, horizontal crankshaft with a nominal power of $12 \mathrm{HP}$ and 29.5 $\mathrm{kg}$ of weight with electric start with $15 \mathrm{amp}$ generator and a 3.5 liter fuel tank, has a 3 gears speed reducer 5: 1 gear reducers what makes a total reduction of 125: 1 , so when the engine is at its maximum efficiency point (3600 rpm), it makes the wheels have 29 RPM, which with a perimeter of 1.7 meters give a distance of 50 meters that runs in a minute (Figure 2).

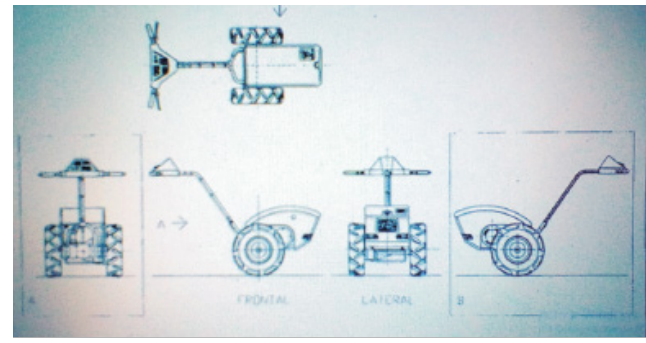

Figure 2 two wheeled tractor Mexican design. ${ }^{20}$

\section{Agricultural small tractor}

Diaz $^{21}$ proposes the design of an agricultural Small tractor although in reality it is a two wheelstractor that has a Briggs \& Stratton 11 HP model 254422 and an Agria model 762-100-800-894 transmission and Firestone R 13 " 5.0 x 10 wheels for tractor which together with the engine and transmission. They are mounted on a 13 "steel chassis (Figure 3).

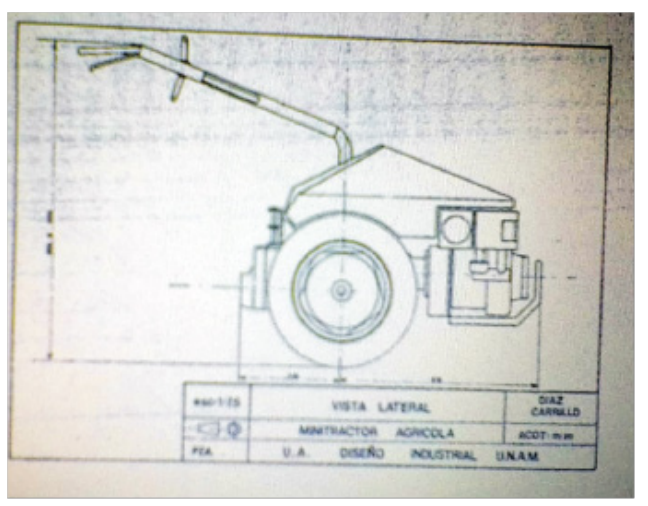

Figure 3 two wheeled tractor Mexican design. ${ }^{21}$ 


\section{Home made two wheels tractor in Mexico}

In Mexico some farmers with blacksmith skills have made some prototypes of two wheeled tractors (Figure 4).

\section{Two wheels tractors in Mexico manufacturing}

In Mexico, no two wheels tractors are manufactured, they are only distributed, the following table lists the brands of two wheels tractors distributed in the country (Table 1).

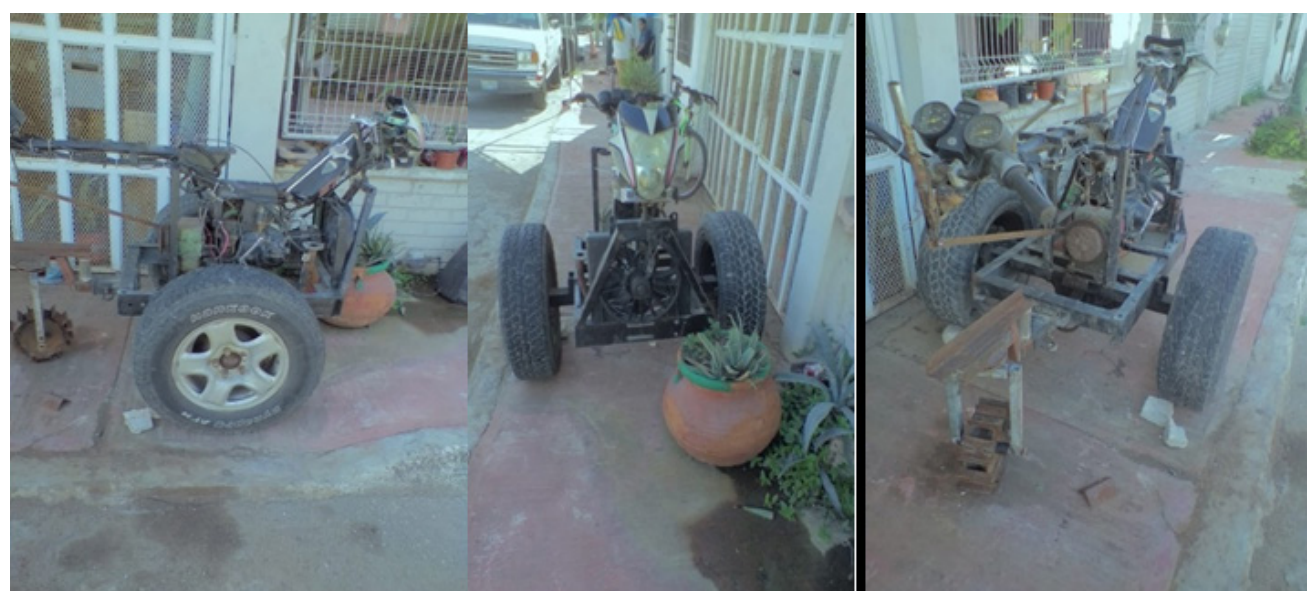

Figure 4 Homemade two wheeled tractor Mexican design.

Table I Distributors and brands of two wheeled tractors in Mexico. Cuapantecatl (20I6)

\begin{tabular}{|c|c|c|c|c|}
\hline BRAND & Distribuitors & MODEL & $\begin{array}{l}\text { Maximum } \\
\text { power PTO } \\
(\mathrm{Kw})\end{array}$ & Engine power \\
\hline NIBBI & Swissmex Rapid S.A.deC.V. & KAM5 & 6.68 & I3HP \\
\hline \multirow[t]{2}{*}{ Pasquali } & Swissmex Rapid S.A.deC.V. & MC SB30Play GX270 & 4.48 & $8.04 \mathrm{HP}$ \\
\hline & & MC XB40Play I5LD440 & 6.4 & $10.96 \mathrm{HP}$ \\
\hline GRILLO & SwissTrac S.A.deC.V. & GI07D,G85D & 7.48 & IIHP \\
\hline \multirow[t]{3}{*}{ RAPID } & SwissTrac S.A.deC.V. & EURO & & $16 \mathrm{HP}$ \\
\hline & & UNIVERSO & & $\mathrm{I} 3 \mathrm{HP}$ \\
\hline & & MONDO & & 9HP \\
\hline \multirow{6}{*}{ BCS } & & 740ACTPSI5DL440 & 5.9 & $10.86 \mathrm{HP}$ \\
\hline & & 750PS3LD5I 0 & 7.1 & $12.06 \mathrm{HP}$ \\
\hline & & MC730PSGX340 & 7.1 & $10.6 \mathrm{HP}$ \\
\hline & & MC720PSGX270 & 4.9 & $8.04 \mathrm{HP}$ \\
\hline & & MC738PSGX340 & 6.23 & $10.6 \mathrm{HP}$ \\
\hline & & MC728PSGX270 & 4.89 & $8.04 \mathrm{HP}$ \\
\hline GOLDONI & CARRERA S.A.deC.V. & GLMTCI40EE & & $16 \mathrm{HP}$ \\
\hline ASIA TECH & Sistemas Multiprogresivos S.A.deC.V. & AMC-880M & 4.5 & $7.91 \mathrm{HP}$ \\
\hline BERTOLINI & Gimbel Mexicana S.A.deC.V. & 410 & 5.14 & IIHP \\
\hline FERRARI & KarvsProjardín\&Agro S.A.deC.V. & MC338PSGX340 & 7.18 & $10.73 \mathrm{HP}$ \\
\hline
\end{tabular}


Table continue

\begin{tabular}{|c|c|c|c|c|}
\hline BRAND & Distribuitors & MODEL & $\begin{array}{l}\text { Maximum } \\
\text { power PTO } \\
(\mathrm{Kw})\end{array}$ & Engine power \\
\hline & & MC340PSGX390 & 7.47 & II.66HP \\
\hline & & MC340PSLI00 & 7.07 & $\mathrm{IOHP}$ \\
\hline & & MC338PSGX270 & 4.55 & 8.04HP \\
\hline \multirow[t]{2}{*}{ HUSQVARNA } & Mquinaria del Pacífico S.A.deC.V. & TR430 & & 5.7HP \\
\hline & & TR530 & & 7HP \\
\hline \multirow[t]{2}{*}{ MEKATECH } & Grupo Comercom S.A.deC.V. & МКT-MM-II & & IIHP \\
\hline & & MKT-MM-I4 & & $\mathrm{I} 4 \mathrm{HP}$ \\
\hline MAKITA & Makita Mexico & KRQ75IH & & 6.3HP \\
\hline John Merson & Antarix S.A.deC.V. & MMI80 & & $\mathrm{I} 8 \mathrm{HP}$ \\
\hline
\end{tabular}

\section{Testing of two wheels tractors in Mexico}

In Mexico, the institution responsible for testing two wheels tractors is INIFAP(National Institute of Forestry, Agricultural and Livestock Research) through the agricultural CENEMA (National Center of Agricultural Machinery Standardization) and the person responsible for certifying them is the OCIMA (Certification Body for Agricultural Implements and Machinery). Two wheels tractor have recently acquired importance in Mexican agriculture because they are easy to handle for small areas, for them CENEMA also has a test protocol to evaluate and determine the quality of work they present. PPM-C0408/2 test protocol whose objective is to determine the power to the power take-off of the two wheels tractors, traction power and performance in the field with their respective implements and there is also the Mexican standard for test of two wheels tractors. In our country there are no reported works of two wheels gtractor tests in addition to CENEMA only that of Yam Tzec ${ }^{22}$ who evaluated A walking tractor with two implements plow and cultivator. The methodology used for the evaluation was the NMX-O-182-SCFI-2003 adapted. It is recommended to use the rototiller in small surfaces or in areas where a tractor conventional cannot have access to perform work, as well as in greenhouses, shade house and in work of minimum requirements of traction.

Likewise, OCIMA has certified until 2018 the following brands and models of two wheels tractor for the support of small farmers (Table 2). ${ }^{23-28}$

Table 2 Two wheels tractors certified by the OCIMA until 20I8.INIFAP.2019

\begin{tabular}{|c|c|c|c|}
\hline Distribuidor & Marca & Modelo & $\begin{array}{l}\text { Potencia máxima } \\
\text { certificada a la TDF (kW) }\end{array}$ \\
\hline Swissmex Rapid, S.A. de C.V & $\mathrm{NIBBI}$ & KAM5 & 6.68 \\
\hline Swissmex Rapid, S.A. de C.V. & PASCUALI & MC SB30 PLAY GX270 & 4.48 \\
\hline Swissmex Rapid, S.A. de C.V. & PASCUALI & MC XB40 PLAY I5LD440 & 6.4 \\
\hline Swissmex Rapid, S.A. de C.V. & PASCUALI & MC XB40 PLAY I5LD440 & 5.03 \\
\hline SWISSTRAC S.A. de C.V. & Grillo & GI07D, G85-D & 7.48 \\
\hline $\begin{array}{l}\text { Concesionaria Reyes Salcedo } \\
\text { S.A. de C.V. }\end{array}$ & BCS & MC740PSGX390 & 7.22 \\
\hline $\begin{array}{l}\text { Concesionaria Reyes Salcedo } \\
\text { S.A. de C.V. }\end{array}$ & BCS & 740ACTPSI5LD440 & 5.9 \\
\hline $\begin{array}{l}\text { Concesionaria Reyes Salcedo } \\
\text { S.A. de C.V. }\end{array}$ & BCS & 750PS3LD510 & 7.1 \\
\hline $\begin{array}{l}\text { Concesionaria Reyes Salcedo } \\
\text { S.A. de C.V. }\end{array}$ & $\mathrm{BCS}$ & MC730PSGX340 & 7.1 \\
\hline $\begin{array}{l}\text { Concesionaria Reyes Salcedo } \\
\text { S.A. de C.V. }\end{array}$ & BCS & MC720PSGX270 & 4.9 \\
\hline $\begin{array}{l}\text { Concesionaria Reyes Salcedo } \\
\text { S.A. de C.V. }\end{array}$ & BCS & MC738PSGX340 & 6.23 \\
\hline $\begin{array}{l}\text { Concesionaria Reyes Salcedo } \\
\text { S.A. de C.V. }\end{array}$ & $\mathrm{BCS}$ & MC728PSGX270 & 4.89 \\
\hline
\end{tabular}




\begin{tabular}{|c|c|c|c|}
\hline Distribuidor & Marca & Modelo & $\begin{array}{l}\text { Potencia máxima } \\
\text { certificada a la TDF }(\mathrm{kW})\end{array}$ \\
\hline $\begin{array}{l}\text { Sistemas Multiprogresivos S.A. } \\
\text { de C.V. }\end{array}$ & AsiaTech & AMC-880M & 4.50 \\
\hline Gimbel Mexicana S.A. de C.V. & Bertolini & 410 & 5.14 \\
\hline Gimbel Mexicana S.A. de C.V. & Bertolini & 411 & 6.5 \\
\hline Swissmex Rapid, S.A. de C.V. & Pascuali & MCXB40GX270 & 5.03 \\
\hline $\begin{array}{l}\text { Karvs Pro Jardín \& Agro, S.A. } \\
\text { de C.V. }\end{array}$ & Ferrari & MC 338 PS GX340 & 7.18 \\
\hline $\begin{array}{l}\text { Karvs Pro Jardín \& Agro, S.A. } \\
\text { de C.V. }\end{array}$ & Ferrari & MC 340 PS GX390 & 7.47 \\
\hline $\begin{array}{l}\text { Karvs Pro Jardín \& Agro, S.A. } \\
\text { de C.V. }\end{array}$ & Ferrari & MC 340 PS LI 00 & 7.07 \\
\hline $\begin{array}{l}\text { Karvs Pro Jardín \& Agro, S.A. } \\
\text { de C.V. }\end{array}$ & Ferrari & MC 338 PS GX270 & 4.55 \\
\hline
\end{tabular}

Note: The mention of trademarks of specific equipment, instruments or materials is due to identification purposes, there being no promotional commitment in relation to them, neither by the authors nor by the publisher

\section{Conclusion}

From the analysis of the current situation of the two wheeled tractor in Mexico, it is concluded that measures must be taken to start the manufacture of this type of tractors in the country, as it would be the first step to start the manufacture of tractors in Mexico , because both of these simple and other types of tractors are of foreign design and only some two-axis models are assembled in Mexico, it would be beneficial to start at least with these simple machines, as there are national design prototypes, there is also infrastructure for the evaluation and testing, only the decision of entrepreneurs and government support to start manufacturing in the country is missing. Also From the literature review made it was found that in Mexico there are no statistics on the amount of two wheels tractors, so it is recommended that government entities implement it in the future.

\section{Funding}

None.

\section{Acknowledgments}

None.

\section{Conflicts of interest}

Authors declare no conflict of interest exists.

\section{References}

1. Emami M, Almassi M, Bakhoda H. Agricultural mechanization, a key to food security in developing countries: strategy formulating for Iran. Agric Food Secur. 2018;7:1-12.

2. Mrema GC, Baker D, Kahan D. Agricultural mechanization in subsaharan africa: time for a new look. Food and Agriculture Organization of the United Nations, Rome; 2008.

3. Takeshima H. Custom-hired tractor services and returns to scale in smallholder agriculture: aproduction function approach. Agric Econ. $2017 ; 48 ; 363-372$
4. Takeshima H, Nin-Pratt A, Diao X. Mechanization and agricultural technology evolution, agricultural intensification in Sub-Saharan Africa: Typology of agricultural mechanization in Nigeria. Am J Agric Econ. 2013;95:1230-1236

5. Pingali P. Agricultural mechanization: Adoption patterns and economic impact, In: Evenson R \& Pingali P. editors. Handbook of Agricultural Economics. North Holland, Amsterdam. 2007;2779-2805.

6. Sims BG, Kienzle J. Farm power and mechanization for small farms in sub-Saharan Africa. Food and Agriculture Organization of the United Nations, Rome. 2006.

7. Negrete, Jaime Cuauhtémoc. Rural poverty and agricultural mechanisation policies in Mexico. Journal of Agriculture and Environmental Sciences. 2014;3:45-66.

8. Cadena ZM. Situation of agricultural mechanization in Mexico. In: Agricultural Machinery, Anthology, DGETA, Mexico; 1997.

9. Soto SM. Introducción al estudio de la maquinaria agrícola. México, Edit. Trillas; 1983

10. Binswanger H. Agricultural mechanisation: a comparative historic perspective. World Bank Report ARU-1, Washington; 1982.

11. Negrete JC. Mecanización agrícola en México". México DF, Edición propia. 2006.

12. Negrete JC, Lilles TM. Lilles TMR. Diseño de tractores agrícolas en México. Revista Ciencias Técnicas Agropecuarias. 2012;21(1):05-11.

13. Negrete JC, Lilles TM, Lilles TMR. Parque de tractores agrícolas en México: estimación y proyección de la demanda. Revista Ciencias Técnicas Agropecuarias. 2013;22(3):61-69.

14. Negrete JC. Agricultural mechanization key to recovery of agriculture of developing countries. Acta Scientific Agriculture 2018;2(12).

15. Veerangouda M, Sushilendra ER, Anantachar M. Development and evaluation of multipurpose tool carrier for power tiller. Dept. of farm power and machinery college of agricultural engineering raichur - 584 102, Karnataka, India. 2009

16. PS Tiwari, AC Varshney. Power tiller, A potential source for rural employment. Productivity. 1995;36(3). 
17. Ortiz-Cañavate J, Hernanz MJL. Técnica de la mecanización agraria 3rd edn. Madrid: Mundi Prensa, 1989:643.

18. Lara-lopez, WJ Chancellor. Two-wheel tractors for dry land farming. CIGR Handbook of Agricultural Engineering. Plant production Engineering. 1990.

19. Lara LA. Design and development of a two wheeled tractor for production by small scale manufacturers in México. Doctoral Engineering Dissertation, University of California, Davis, California, USA; 1979.

20. Zarate. Sistema motocultor agrícola. B.Sc. Industrial Designer thesis UNAM. México. 1999.

21. Diaz PS. Minitractor Agrícola. B.Sc.Industrial Designer.UNAM México. 1990.

22. Yam-Tzec JA, Santos-Chávez A, Pérez-Ortiz S, et al. Testing of technical and operational factors of a walking tractor with plow and cultivator. Revista Ciencias Técnicas Agropecuarias. 2019;28(1).
23. Cuapantecatl GN. Catalogo de tractores,motocultores e implementos para pequeños productores. Bsc. Thesis Chapingo. Autonomous University. Texcoco. Mexico. 2016.

24. Lara LA. Trends and requirements of mechanization: the case of México. In: 1st Latin-American Meeting of the Club of Bologna, Fortaleza, Brazil; 2000:20-31.

25. Mehta CR, Pajnoo RK. Role of Japan in promotion of agricultural mechanization in India. Agricultural Mechanization in, Africa, and Latin America. 2013;44:4

26. Mialhe LG. Agricultural machinery tests \& certification, Piracicaba, SP Brazil. Fundaçao de Estudos Agrarios Luis de Quiroz. Brazil

27. http://www.inifap.gob.mx/SitePages/productos_servicios/motocultores. $\operatorname{aspx}$

28. Guanghuo W, Roetter RP. The impact of increasing farm size and mechanization on rural income and rice production in Zhejiang province. China. Agric Syst. 2007;94:841-850. 